\title{
Typha capensis (Rohrb.) N.E.Br. (Typhaceae): morphology, medicinal uses, biological and chemical properties
}

\author{
Collen Musara \& Elizabeth Bosede Aladejana* \\ Medicinal Plants and Economic Development (MPED) Research Centre, Department of Botany, University of Fort Hare, Private Bag X1314, \\ Alice 5700, South Africa \\ *Email: ealadejana@ufh.ac.za
}

\section{ARTICLE HISTORY}

Received: 23 July 2020

Accepted: 16 September 2020

Published: 01 October 2020

KEYWORDS

Bulrush

Cat's tail

Biological activities

Ailments

Herbal medicine

Southern Africa

\begin{abstract}
Typha capensis (Rohrb.) N.E.Br. is a robust, monoecious, perennial marshy herb that belongs to the family Typhaceae. The current research aims to provide a comprehensive analysis of the biological and chemical properties, botany and medicinal uses of $T$. capensis. Comparative analysis of literature showed that $T$. capensis is a medicinal plant that has multiple benefits such as food for humans, feeds for animals and medicines to treat various diseases. All the parts including the leaves, seeds, rhizomes and pollen can be used in making decoction to improve male potency and libido, cures genital problems, boosts circulation, enhance female fertility, strengthens uterine contraction in childbirth and facilitates placenta removal. It is also used for the treatment of dysmenorrhea, diarrhoea and dysentery venereal diseases. The plant contains several flavones and phenolic compounds which have been reported to possess anti-inflammatory activity. Scientific studies have shown that $T$. capensis has a broad range of biological activities such as antibacterial, antioxidants, fertility-promoting effect and apoptosis effect. T. capensis should be subjected to comprehensive phytochemical, pharmacological and toxicological assessments projected at assessing its efficacy and safety as herbal medicine.
\end{abstract}

\section{Introduction}

The family Typhaceae is composed of approximately 10 to 15 species which are tall and capable of reproducing clonally through submerged rhizomes forming dense stands (1). Typha capensis (Rohrb.) N.E.Br. is a vigorous, herbaceous perennial plant known as bulrush (English), Lesehu (Sepedi / NorthSotho), papkuil or matjiesriet or palmiet (Afrikaans.), Ibhuma (Zulu, Swazi), Ingcongolo (Xhosa) and Motsitla (Sesotho) which belongs to the family Typhaceae $(2,3)$. The word Typha is derived from typhos, a Greek word which means marsh, referring to the habitat, or typhe, which is a cat's tail, alluding to their inflorescence (1). Its specific name capensis is derived from its abundance in the Cape (1).

A study on the morphology, medicinal uses, phytochemistry and biological activities of $T$. capensis was carried out using material from existing scientific databases such as Google Scholar, Science Web, SciFinder, Scopus, Science Direct, PubMed, Scielo,
Springer Link, Google Patents, BioMed Central (BMC) and Medline. To avoid too much filtering of literature, the search terms were done individually. Keywords of the quest include the scientific name and synonyms, common English names, biological activity, medicinal uses, ethnobotany, ethnopharmacology, pharmacology, phytochemistry of $T$. capensis and therapeutic value. Complementary information was gathered from related scientific publications collected from the University of Fort Hare Library, Alice campus in South Africa.

The economic value and intrinsic benefits of medicinal plants have gained widespread recognition, as is their potential for development from use as traditional into future medicines. T. capensis is an example of these plants. In this study, its medicinal applications, phytochemistry and pharmacological activities are critically reviewed. This study documents the existing indigenous/traditional knowledge related to the use of $T$. capensis that can be used for future research.

(c) Musara \& Aladejana (2020). This is an open-access article distributed under the terms of the Creative Commons Attribution License, which permits unrestricted use, distribution and reproduction in any medium, provided the original author and source are credited (https://creativecommons.org/licenses/by/4.0/).

To cite this article: Musara C, Aladejana E B. Typha capensis (Rohrb.) N.E.Br. (Typhaceae): morphology, medicinal uses, biological and chemical properties. Plant Science Today. 2020;7(4):578-583. https://doi.org/10.14719/pst.2020.7.4.872 


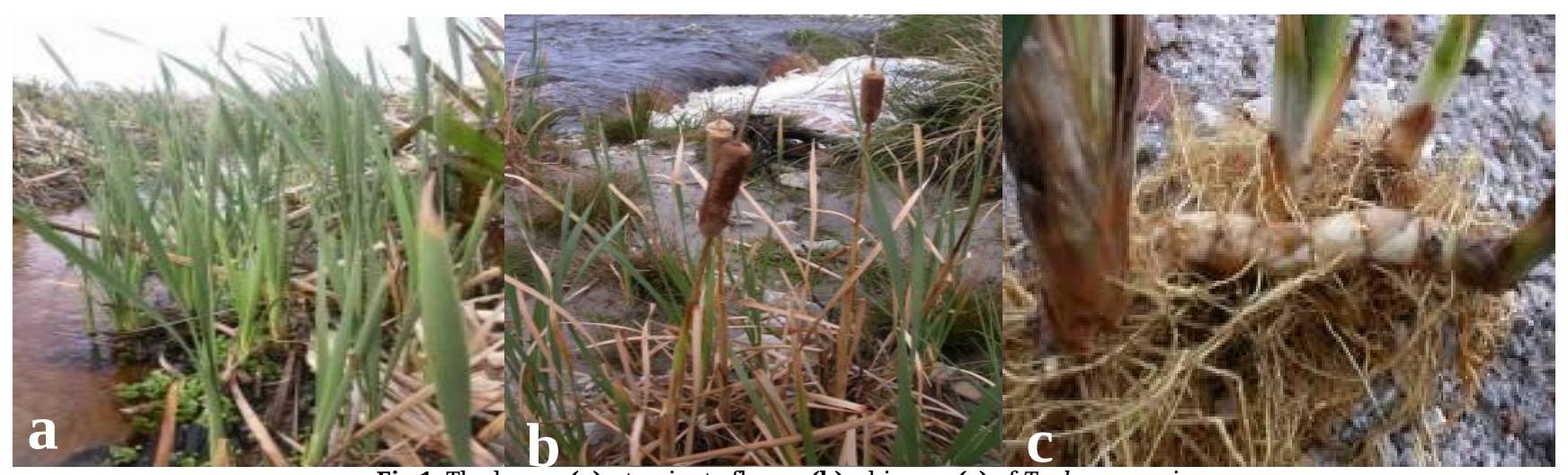

Fig.1. The leaves (a), staminate flower (b), rhizome (c) of Typha capensis

Source: (7)

\section{Results and Discussion}

\section{Morphological Description}

Typha capensis is a monoecious, perennial marshy herb, and it colonises its habit proficiently through its creeping rhizomes $(3,4)$. It is a robust plant with a reed-like appearance and grows up to three metres in height with thick, fleshy, spongy and creep rhizomes (Fig. 1) (4). The most distinguishing characteristic of $T$. capensis is the erect and simple, strappy and hairless, amphibious with long, grey-green stems that obtrude from the rhizomes into thick stands. The leaves are linear, long braided, hairless, bluish-grey to green, strap-shaped with parallel veins and varying in length from $0.5-1.5 \mathrm{~m}$ and more. The inflorescence is a thick spike of densely packed flowers, at first pink, and then turning brown (4). They are usually contiguous but may be separated by as much as $2 \mathrm{~cm}(4,5)$. This has unisexual minute flowers lacking tepals, reduced to 1 carpel or $2-5$ stamens and filled with hair (4). The characteristic stalk of the flower bears minute male flowers towards the top, with the female flowers $(12-32 \mathrm{~cm}$ long) packed in a dense brown mass under the male part (5). The male spike is $8-15 \mathrm{~cm}$ long and when mature falls off; leaving the 'bean' bulrush, which is the plant's fruiting component (6). The fruit is oneseeded follicle with stigma and hairs of the female flower forming a pappus that aid in dispersal (5). $T$. capensis flowers from December to January $(3,4)$. The thick fibrous roots emerging from the rhizomes assist in the plant's anchorage, allowing it to withstand heavy winds without being washed into the water $(3,4)$.

\section{Distribution and Habitat}

Typha capensis is an indigenous perennial aquatic $\mathrm{C}_{3}$ plant which grows in the wetlands of South Africa and can tolerate both acidic and alkaline environments and some degree of salinity (2). The plant primarily inhabits marshes, stream banks, dams and lakes and their muddy substratum allows the plant to anchor its rhizomes firmly (8). The rhizome structure shows both hydric and xeric adaptations due to variation in the water content of marsh ecosystems (4). Mechanical and conductive tissue is common in T. capensis and signifies the mesophytic ability of the plant due to ample parenchyma, aerenchyma and hydrophytic tissue storage (4). Typha capensis is primarily distributed in most South African provinces (Eastern Cape, Free
State, Gauteng, KwaZulu-Natal, Limpopo, Mpumalanga, North West and North Western Cape) (2). Bulrushes are found in southern African countries such as Angola, Botswana, Namibia, the DRC, Kenya, Tanzania, Uganda, Malawi, Mozambique, Zambia, Zimbabwe and Swaziland and it is known to spread very quickly and form large clumps $(3,4)$.

\section{Medicinal Uses}

Traditional use of medicines is increasingly recognised as potential future medicines. All the parts of Typha capensis including the leaves, seeds, rhizomes and pollen are used in making the decoction and used in the treatment of various diseases.

The fleshy rhizomes of $T$. capensis are used traditionally in South Africa, Chinese, Japan, Germany and Turkish to make decoctions for the treatment of venereal diseases, dysmenorrhea, diarrhoea and dysentery. It enhances male potency and libido, cures genital disorders, boosts circulation, promotes female fertility, strengthens uterine contraction during childbirth and facilitates placenta removal (9-13).

The leaves of $T$. capensis are diuretic and used to treat dysentery and sexually transmitted diseases (14); the pollen is astringent, desiccant, diuretic, haemostatic and vulnerary (8) and the seed are haemostatic. It has been reported to have antibacterial properties (E. coli) and known for treating nose bleeds, haematemesis, inflammation, haematuria, uterine bleeding, scrofula (Mycobacterial cervical lymphadenitis), painful menstruation, postpartum, abdominal and stomach pain, abscesses and uterine bleeding (15-17).

In addition, the spongy rhizomes of $T$. capensis are rich in starch and can be crushed to a meal, whereas the pollen is used as high protein-based food. The leaves are often used in making handbrooms as well as in weaving and thatching in Sekhukhune land, South Africa (8). Other benefits include papermaking, torch making (female inflorescences dipped in kerosene), water purification, green manure and home making (leaves were used to insulate roofs of early houses). The immature flowering spikes-raw are cooked or made into a soup, and the seeds can be ground into a flour and used in making cakes (18). 


\section{Pharmacological Properties}

Several activities have been reported from the leaves and rhizome extracts of Typha capensis, and they include anti-inflammatory, antibacterial, antioxidants, fertility-promoting effect and apoptosis effect. The effect of the aqueous, hexane, acetone, ethanol and methanol leaves and rhizomes extracts of $T$. capensis are discussed below.

\section{Anti-inflammatory properties}

The anti-inflammatory activity of hexane, acetone, ethanol, methanol and aqueous leaf extracts of $T$. capensis was examined through the inhibition of 15lipoxygenase (15-LOX) and nitric oxide (NO) by lipopolysaccharide (LPS)-activated RAW 264.7 murine macrophages, and quercetin as the positive control (17). Among the extracts, the hexane extract inhibited 15-LOX inhibitory with the $\mathrm{IC}_{50}$ values of $4.65 \mu \mathrm{g} / \mathrm{mL}$, which was significantly higher than quercetin at the $\mathrm{IC}_{50}$ values of $24.60 \mu \mathrm{g} / \mathrm{mL}$. Following fractionation, the methanol/water (35\%) and hexane fractions of $T$. capensis exhibited good activity against 15-LOX with the $\mathrm{IC}_{50}$ values of 9.15 and $10.19 \mu \mathrm{g} / \mathrm{mL}$ respectively. Besides, the acetone extract demonstrated strong inhibitory activity (86\%) against NO production and cell viability of $97 \%$ at $50 \mu \mathrm{g} / \mathrm{mL}$. The most active fraction of the extract was butanol, inhibiting $94.6 \%$ and $77.39 \%$ of NO production at 100 and $50 \mu \mathrm{g} / \mathrm{mL}$ respectively, with $100 \%$ of cell viability at $12.5 \mu \mathrm{g} / \mathrm{mL}$. The plant extracts with strong inhibitory activity in terms of nitric oxides production and lower toxicity are useful in reducing inflammation, thus supporting the plant's medicinal use against inflammation (17).

Phenolic compounds have been reported to possess anti-inflammatory properties through the inhibition of reactive nitrogen species, 15-LOX, reactive oxygen species and cyclooxygenase pathways. The reactive nitrogen species and reactive oxygen species serve as secondary messengers and are closely related to acute and chronic inflammation (19-21). Also, flavonoids have good antiinflammatory activity, improve the body's normal functioning against viruses and carcinogenic agents. This activity is due to the connection between the phenolic hydroxyl groups and the structures of flavonoid $(22,23)$. Thus, $T$. capensis may contain good activity against free radicals.

\section{Antioxidant properties}

The antioxidant activity of the hexane, acetone, ethanol, methanol and aqueous leaf extracts of $T$. capensis was examined using free radical scavenging 2, 2-diphenyl-1-picrylhydrazyl (DPPH) and electron reducing 2,2'-azino-bis (3-ethylbenzothiazoline-6sulfonic acid (ABTS) assays (17). The acetone extract exhibited the strong activity against DPPH with the $\mathrm{IC}_{50}$ values of 7.11 and $1.91 \mu \mathrm{g} / \mathrm{mL}$ against ABTS, which was comparable to the positive controls, trolox and ascorbic acid with 2.13 and $2.49 \mu \mathrm{g} / \mathrm{mL} \mathrm{IC}_{50}$ levels respectively. Ethyl acetate and butanol fractions of the plant showed good antioxidant activities with the $\mathrm{IC}_{50}$ values of 5.61 and $9.98 \mu \mathrm{g} / \mathrm{mL}$ against DPPH and ABTS respectively. Study on the antioxidant activity of the leaves and rhizome extracts using DPPH radical scavenging and vitamin $\mathrm{C}$ as the positive control (8), revealed that the extracts showed low antioxidant activity (12.8\%) after spraying the chromatogram with $0.2 \% \mathrm{DPPH}$; however, the positive control had $100 \%$ scavenging activity.

The capability of $T$. capensis leaves and rhizomes extracts to scavenge reactive oxygen species was examined (24) by making use of chemiluminescent ABEL, peroxynitrite anion-specific antioxidant kits and free radicals like superoxide anion containing Pholasin at concentrations of $0.1,0.5$ and $1.0 \mathrm{mg} / \mathrm{mL}$. The extract showed significant dose-depended scavenging of superoxide formation varying from $10.2 \%$ for $1.0 \mathrm{mg} / \mathrm{mL}$ rhizome extract to $57.5 \%$ for 1 $\mathrm{mg} / \mathrm{mL}$ leaves extract and peroxynitrite ranging from $45.1 \%$ for $0.1 \mathrm{mg} / \mathrm{mL}$ rhizome to $98.6 \%$ for 1 $\mathrm{mg} / \mathrm{mL}$ leaves extract. Hence, the leaves demonstrated a greater scavenging activity for both superoxide and peroxynitrite formation compared to the rhizome extract. Also, further study showed that the extracts had a higher inhibiting capacity for the inhibition of collagenase activity in a dose-dependent manner; thus, the plant could possibly have anticancer effects (24). This is significant as collagen inhibition can decrease the invasive ability of cancer cells and affect the formation of the basement membrane in-vivo (25).

\section{Antimicrobial activity}

The antibacterial potential of the hexane, dichloromethane, acetone and methanol leaves and rhizomes extracts of $T$. capensis were evaluated using microplate dilution method (8). All the extracts had antimicrobial activity with the rhizomes and leaf methanol extracts exhibiting greater activity against $P$. aeruginosa, $S$. aureus, $E$. coli and $E$. faecalis, with the average minimum inhibitory concentration (MIC) of 0.75 and $0.21 \mathrm{mg} / \mathrm{mL}$ respectively, whereas the MIC of the positive control (ampicillin) ranged from $0.08-0.16 \mathrm{mg} / \mathrm{mL}$. The study further revealed that the leaf extracts were more active than the rhizome extracts; thus, validates in a systemic way, the antibacterial properties of $T$. capensis.

\section{Fertility-promoting effect}

The fertility-promoting effects of the aqueous rhizomes extract of $T$. capensis in a rat model of cadmium-induced infertility was evaluated (26), which showed that it does not improve $(p>0.05)$ testicular and epididymal weights at the doses used in the study, but, it slightly raised the sperm count by $14 \%, 31 \%$ and $35 \%$ respectively, in the experimental groups treated with the extract at doses 100, 200 and $400 \mathrm{mg} / \mathrm{kg}$ compared to the $\mathrm{CdCl}_{2}$ control group. The authors concluded that $T$. capensis in an animal model of cadmium-induced infertility, could not provide protective effects against oxidative stress or promote fertility.

The in-vitro effects of aqueous leaves and rhizome extracts of $T$. capensis was investigated on male fertility on human sperm functions (24). The findings revealed that at $1 \mathrm{hr}$, the rhizome extract significantly reduced the values of all measured sperm parameters namely motility, vitality, sperm 
production of reactive oxygen species and sperm with intact mitochondrial membrane potential. This could be because of the direct toxic effect of some $T$. capensis extract components on the mitochondria resulting in a respiratory breakdown, or an indirect effect due to the complete scavenging of the free radicals generated in any cell during aerobic respiration, where approximately $1-5 \%$ of the oxygen consumed is transformed into free radicals (27), or as a result of ROS which has been reported to be harmful and causes cell death, male infertility and reduced sperm motility (28-30). The study concluded that in contrast to the proposed use by traditional healers as a natural remedy for treating male fertility disorders, the extracts have detrimental effects on sperm functions in-vitro. Hence, further studies are needed using the animal model in an in-vivo testing to ascertain the beneficial effects of $T$. capensis on male reproductive functions.

Another study investigated the effects of rhizome extract F1 fraction of $T$. capensis obtained during autumn, winter, spring and summer harvests on TM3-Leydig cells at different concentrations of $0.01,0.02,0.1,1,10$ and $100 \mu \mathrm{g} / \mathrm{mL}$ for 24, 48 and 96 hrs (31). After $48 \mathrm{~h}$ of exposure, F1 fraction of all four seasons strongly increased the production of testosterone in TM3 cells with maximal impact at 0.1 $\mu \mathrm{g} / \mathrm{mL}$, in a dose-dependent manner. Lesser testosterone production was observed at higher concentrations. Thus, it was concluded that the F1 fraction of an aqueous extract of $T$. capensis rhizomes greatly increased the production of testosterone and may be useful to treat male infertility and male ageing problems (31). From the above results, further in-vivo and clinical studies are required in other to thoroughly investigate the aqueous rhizome extract of the plant for its ability to treat male infertility as claimed by the traditional healers.

\section{Cytotoxic effects}

The early apoptotic events by means of Annexin VCy3 (AnnCy3) binding to TM3 cells was determined in a study (31). The result revealed that the rhizome extract F1 fraction of $T$. capensis showed no cytotoxic effects including cell viability, induction of apoptosis and DNA fragmentation at concentrations used in the study. There are limited literature on the cytotoxicity effect of this plant. Thus, further toxicological assessment of the plant is required in order to ascertain the safety of the plant.

\section{Chemical Properties}

The Typha genus has been reported to contain numerous flavones, phenolic compounds (32), longchain hydrocarbons and various triterpenoids with a steroidal skeleton of typhasterols $(16,32)$. Research has also shown that the presence of phytosteroids in Typha capensis can be metabolised by the body resulting in the creation of an androgen or oestrogenlike substances that are beneficial to male sex drive and performance (8).

Phenolic compounds such as typhaphthalide, typharin, sitosterol, the flavonoids afzelekin, epiafzelekin, (+)-catechin and (-)-epicatechin were isolated and identified from $T$. capensis rhizomes
(33). Some of this compounds, for instance, sitosterol, have been reported to prevent chronic inflammation caused by obesity, with a clear negative Pearson correlation between pro-inflammatory cytokines such as TNF- $a$ and IL-6 and the serum sistosterol tested in animal and clinical studies (34). Also, (-)epiafzelekin, a flavan-3-ol compound has antioxidant and anti-inflammatory activities (35, 36), (-)epicatechin reduced the expression of proinflammatory cytokines (TNF-a, IL-6) and showed protection against LPS-induced renal dysfunction, reducing the inflammatory damage.

Also, the total phenolic content of $45.29 \pm 0.86$ mg GAE / g was obtained in ethanol crude extract of T. capensis and the values of $37.79 \pm 1.94 \mathrm{mg} \mathrm{GAE} / \mathrm{g}$ in ethyl acetate fraction of the extract (17). In addition, Ilfergane (37) identified quercetin and naringenin from an aqueous rhizome extract of $T$. capensis. These compounds showed increased production of testosterone in TM3-Leydig cells at low concentration. They might probably be useful in the treatment of infertility and ageing male malfunctions.

The presence of mineral elements such as $\mathrm{Ca}, \mathrm{Mg}$ and Fe have reported in T. capensis, Centella asiatica and Cyperus longus (38). The highest concentration of $\mathrm{Ca}$ and $\mathrm{Fe}$ were observed in $\mathrm{T}$. capensis with the values of $7246.22 \mathrm{mg} / \mathrm{kg}$ and $268.17 \mathrm{mg} / \mathrm{kg}$ during spring respectively. However, the highest $\mathrm{Mg}$ concentration of $118.78 \mathrm{mg} / \mathrm{kg}$ was also found in $T$. capensis during autumn. It was reported that $T$. capensis contains $\mathrm{Ca}, \mathrm{K}, \mathrm{Mg}, \mathrm{Na}, \mathrm{Fe}$ and $\mathrm{Zn}$ which are essential nutrients and have reportedly been used for the treatment of infertility and sexual performance enhancement (39). Calcium has been reported to play an important role in bones and teeth formation, proper heart and muscles functioning, penile erection and sustenance or triggering sexual desire in males (40-43).

In addition, several biochemical and physiological processes including muscle coupling, contraction and excitation, spermatozoa motility, nerve excitable regulation, egg fertilisation and cell reproduction require calcium (44). A high concentration of magnesium could enhance the production of androgen, estrogens, hormones and neurotransmitters through numerous mechanisms to trigger sexual desire in males. $(41,42,45)$. Sodium and potassium helped in the maintenance of human body tissues excitability, ionic balance, gastric juice formation in the stomach and contraction of muscles. The erectile function in penile tissue is enhanced with potassium induction on vascular smooth muscle (41, 42, 46). Iron helps in the formation of haemoglobin (47) while zinc plays a key role in the primary functioning of cellular processes in all living organisms and helps with restoring the human immune system after illness (48).

\section{Conclusion}

Typha capensis, a monoecious, rhizomatous, perennial herb is widely distributed throughout southern Africa. The study reviewed the medicinal 
uses, chemical and pharmacological properties of $T$. capensis emphasising its antimicrobial, fertility promoting effect, anti-inflammatory, antioxidant and cytotoxicity effects. The empirical evidence for its phytochemical and pharmacological properties suggests the species therapeutic potential. T. capensis is one of the medicinal plants that have multiple uses including the treatment various diseases in tropical Africa. However, detailed studies on the clinical assessment of crude extracts and compounds derived from the $T$. capensis using in-vivo models are required. To evaluate the effectiveness and safety of this plant as herbal medicine, $T$. capensis should be subjected to comprehensive phytochemical, pharmacological and toxicological assessments, since, there are little information on these aspects.

\section{Acknowledgements}

The authors would like to express their gratitude to the Govan Mbeki Research and Development Centre (GMRDC), University of Fort Hare for financial support to conduct this research.

\section{Authors' contributions}

The authors contributed equally to the writing, reading and approved the final manuscript.

\section{Conflict of interests}

The authors declare that they have no conflict of interests.

\section{References}

1. Vázquez FM, Halder S, Venu P, Daniel P. Lectotypification of Typha angustifolia (Typhaceae). Taxon. 2013;62:1283-6. http://dx.doi.org/10.12705/626.18

2. Van Wyk BE, Oudtshoorn BV, Gericke N. Medicinal Plants of South Africa. Briza; 1997.p.304.

3. Hyde MA, Wursten BT, Ballings P, Coates Palgrave M. Flora of Caprivi: Species information: Typha capensis. [cited 2020 June 30]. Available from: https://www.capriviflora.com/speciesdata/ species.php?species_id $=103050$

4. Catarino L, Martins ES. Typhaceae Flora Zambesiaca 2010;13(4):89 - 90.

5. Vlotman N. A Study of Typha capensis (Rohrb.) NE Br: Its biodiversity, role as a potential anti-infective candidate and its effect on metabolism and health [Doctoral dissertation]. University of the Western Cape; 2003.

6. Van Wyk BE \& Gericke N. People's plants. A guide to useful plants of southern Africa. Briza Publications, Pretoria; 2000.

7. South Africa National Biodiversity Institute. Typha capensis. [cited 2020 Feb 16]. Available from: http://pza.sanbi.org/typhacapensis

8. Masoko P, Mokgotho MP, Mbazima VG, Mampuru LJ. Biological activities of Typha capensis (Typhaceae) from Limpopo Province (South Africa). Afri J Biotechnol. 2008;7(20):3743-48.

9. Watt JM, Breyer-Brandwijk MG. Medicinal and poisonous plants of southern and eastern Africa, Edinburgh and London, 1962.

10. Pujol J. Naturafrica -The Herbalist Handbook. Jean Pujol Natural Healers Fundation, Durban, 1990.
11. Hutchings A, Scott AH, Lewis G, Cunningham AB. Zulu Medicinal Plants. An inventory. University of Natal Press, Pietermaritzburg, 1996;53-54.

12. Steenkamp V. Traditional herbal remedies used by South African women for gynaecological complaints. J Ethnopharmacol. 2003;86(1):97-08. https://doi.org/10.1016/S0378-8741(03)00053-9

13. Moteetee A, Kose LS. Medicinal plants used in Lesotho for treatment of reproductive and post reproductive problems. J Ethnopharmacol. 2016;194:827-49. http://dx.doi.org/10.1016/j.jep.2016.10.062

14. Maroyi A. Diversity of use and local knowledge of wild and cultivated plants in the Eastern Cape province, South Africa. J Ethnobiol Ethnomed. 2017;13(1):43. https://doi.org/10.1186/s13002-017-0173-8

15. Yeung HC. Handbook of Chinese Herbs and Formulas Institute of Chinese Medicine, Los Angeles. The American Soc Nutr Sci J Nutr. 2004;134:1105-59.

16. Van Wyk BE, Oudtshoorn BV, Gericke N. Medicinal Plants of South Africa. Briza Publications, Pretoria, 2009.p.336.

17. Ondua M, Njoya EM, Abdalla MA, McGaw LJ. Antiinflammatory and antioxidant properties of leaf extracts of eleven South African medicinal plants used traditionally to treat inflammation. J Ethnopharmacol. 2019;234:27-35. https:// doi.org/10.1016/j.jep.2018.12.030

18. Tropical Plants Database Ken Fern. tropical.theferns.info. [cited 2020July 11]. <tropical.theferns.info/viewtropical.php? id=Typha+capensis $>2019$,

19. Nishio K, Horie M, Akazawa Y, Shichiri M, Iwahashi $H$, Hagihara Y, Yoshida Y, Niki E. Attenuation of lipopolysaccharide (LPS)-induced cytotoxicity by tocopherols and tocotrienols. Redox Biol. 2013;1(1):97-103. https://doi.org/10.1016/j.redox.2012.10.002

20. Brüne B, Dehne N, Grossmann N, Jung M, Namgaladze D, Schmid T, von Knethen A, Weigert A. Redox control of inflammation in macrophages. Antioxidants \& redox signaling. 2013;19(6):595-637. https://doi.org/ 10.1089/ars.2012.4785.

21. Mittal M, Siddiqui MR, Tran K, Reddy SP, Malik AB. Reactive oxygen species in inflammation and tissue injury. Antioxidants

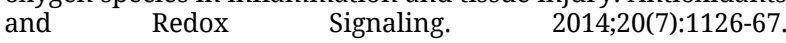
https://doi.org/10.1089/ars.2012.5149

22. Yamamoto Y, Gaynor RB. Therapeutic potential of inhibition of the NF- $\kappa B$ pathway in the treatment of inflammation and cancer. J Clin invest. 2001 15;107(2):135-42. https://doi.org/ 10.1172/JCI11914

23. Pereira RB, Sousa C, Costa A, Andrade PB, Valentão P. Glutathione and the antioxidant potential of binary mixtures with flavonoids: synergisms and antagonisms. Molecules. 2013;18(8):8858-72. https://doi.org/10.3390/molecules18088858.

24. Henkel R, Fransman W, Hipler UC, Wiegand C, Schreiber G, Menkveld R, Weitz F, Fisher D. Typha capensis (Rohrb.) NE Br. (Bulrush) extract scavenges free radicals, inhibits collagenase activity and affects human sperm motility and mitochondrial membrane potential in-vitro: a pilot study. Andrologia. 2012;44:287-94 0272.2011.01179.x

25. Boghaert ER, Sells SF, Walid AJ, Malone P, Williams NM, Weinstein $\mathrm{MH}$, Strange R, Rangnekar VM. Immunohistochemical analysis of the proapoptotic protein Par-4 in normal rat tissues. Cell growth and differentiation: The molecular biology journal of the American Association for Cancer Res. 1997;8(8):881-90. https://doi.org/10.1.1.325.7189

26. Gondwe MM, Mpungose A, Kamadyaapa DR, Shauli M, Ndebia E, Sewani-Rusike C, Iputo J, Oyedeji A. The protective effect of aqueous extract of Typha capensis rhizomes on cadmiuminduced infertility in rats. J Basic Clin Physiol Pharmacol. 2019;30(3). https://doi.org/10.1515/jbcpp-2018-0173

27. Chance B, Sies H, Boveris A. Hydroperoxide metabolism in mammalian organs. Physiol Rev. 1979 59(3):527-605. https://doi.org/10.1152/physrev.1979.59.3.527

28. Aitken RJ, Krausz C. Oxidative stress, DNA damage and the Y chromosome.Reproduction-Cambridge..2001;122(4):497-506. https://doi.org/10.1530/reprod/122.4.497 
29. Sharma RK, Pasqualotto FF, Nelson DR, Agarwal A Relationship between seminal white blood cell counts and oxidative stress in men treated at an infertility clinic. J Androl. 2001;22(4):575-83. 4640.2001.tb02217.x

30. Henkel R, Kierspel E, Stalf T, Mehnert C, Menkveld R, Tinneberg HR, Schill WB, Kruger TF (2005) Effect of reactive oxygen species produced by spermatozoa and leukocytes on sperm functions in non-leukocytospermic patients. Fertil Steril. 2005;83:635-42. https://doi.org/10.1016/j.fertnstert.2004.11.022

31. Ilfergane A, Henkel RR. Effect of Typha capensis (Rohrb.) NE $\mathrm{Br}$. rhizome extract F1 fraction on cell viability, apoptosis induction and testosterone production in TM 3-Leydig cells. Andrologia. 2018:50(2):e12854. https://doi.org/10.1111/and.12854

32. Chapman J, Hall P. Dictionary of Natural Products on CD-ROM. Release 9:1, London, 2000.

33. Shode FO, Mahomed AS, Rogers CB. Typhaphthalide and typharin, two phenolic compounds from Typha capensis Phytochem. 2002;61(8):955-57. https://doi.org/10.1016/S00319422(02)00439-9

34. Kurano M, Hasegawa K, Kunimi M, Hara M, Yatomi Y, Teramoto T, Tsukamoto K. Sitosterol prevents obesity-related chronic inflammation. Biochimica et Biophysica Acta (BBA)Molecular and Cell Biology of Lipids. 2018;1863(2):191-98. https://doi.org/10.1016/j.bbalip.2017.12.004

35. Min KR, Hwang BY, Lim HS, Kang BS, Oh GJ, Lee J, Kang SH, Lee KS, Ro JS, Kim Y. (-)-Epiafzelechin: cyclooxygenase-1 inhibitor and anti-inflammatory agent from aerial parts of Celastrus orbiculatus. Planta Medica. 1999 Jun;65(05):460-2. https://doi.org/10.1055/s-2006-960813

36. Wong KC, Law MC, Wong MS, Chan TH. Development of a UPLC-MS/MS bioanalytical method for the pharmacokinetic study of (-)-epiafzelechin, a flavan-3-ol with osteoprotective activity, in C57BL/6J mice. J Chromatography B. 2014;967:16267.

37. Ilfergane A. Investigations on the effects of Typha capensis on male reproductive functions (Doctoral dissertation), University of the Western Cape, 2016
38. Saibu OS. Analysis of three wetland medicinal plants: Centella asiatica, Cyperus longus and Typha capensis found in the Western Cape Province of South Africa. [Thesis] University of the Western Cape, 2017.

39. Collins BS, Sharitz RR, Coughlin DP. Elemental composition of native wetland plants in constructed mesocosm treatment wetlands. Bioresource Technol. 2005;96(8):937-48. https://doi.org/10.1016/j.biortech.2004.08.005

40. Johnston AE. Trace elements in soil: status and management. Essential trace elements for plants, animals and humans. $2005 ; 7$.

41. Samuel FM, Tetteh MA, Daniel H, György D, Kwadwo NA Daniel B, Mohamed A. Bioinorganic elemental content of the Ghanaian aphrodisiac medicinal plant, Paullina pinnata Linn. (Sapindaceae). Afri J Pharm Pharmacol. 2016;10(11):206-11. https://doi.org/10.5897/AJPP2015.4417

42. Soetan KO, Olaiya CO, Oyewole OE. The importance of mineral elements for humans, domestic animals and plants-A review. Afr J food Sci. 2010;4(5):200-22.

43. Underwood E. Trace elements in human and animal nutrition. Elsevier; 2012.

44. Nordin BE, editor. Calcium in human biology. Springer Science \& Business Media; 2013

45. Aremu MO, Ibrahim H. Mineral content of some plant foods grown in Nigeria: A review. Food Sci Qual Manag. 2014;29(73):2225.

46. Vimala G, Shoba F, Gricilda F. Determination of nutritive value and mineral elements of Ficus benghalensis Linn. Seed. Asian J Pharm Clin Res. 2015;8(4):156-59.

47. Bhowmik S, Badal KD. Elemental analysis of some ethnomedicinally important hydrophytes and marsh plants of India used in the traditional medicine. Asian Pacific J Trop Biomed. 2012;1227-31.

48. Hafeez B, Khanif Y, Saleem M. Role of zinc in plant nutrition- A review. Amer J Exper Agr. 2013;3(2):374. 